\title{
Interest Free Banking and Economic Stability*
}

\author{
HABIB A. ZuBERI
}

Since the end of World War II most colonial and semi-colonial countries have regained their political independence. These countries are now in the process of reorganising and restructuring their economic systems based on their religious, historical and cultural values. Today, there are approximately 50 countries with roughly one billion inhabitants that profess Islam as their religion. During the past two decades an attempt has been made, in varying degrees, in many of these countries to reconstruct the economic structure within the framework of an Islamic system.

The economic system, in an Islamic society, is not significantly different than a welfare state in a capitalist system. Such an economic system is based on the principle of justice $(A l A d l)$ in which the means of production are privately owned, freedom of domestic and international trade is emphasised and one is required to part with 2.5 percent of savings each year to support the needy. The Islamic system differs from the modern capitalist system in a significant way in that borrowing and lending money, based on a predetermined interest rate, is strictly prohibited in Islam, while interest rates have played a major role in the development of the modern banking system and the development of other financial intermediaries.

Islam is not unique in prohibiting or condemning the use of interest (Riba). Plato and Aristotle maintained that money is barren and therefore, it cannot breed money. They denounced Tokos, which means birth of money from money [Mohsin and Abbas (1990)]. Even Judaism which permitted charging interest on loans from Nochri (foreigners) maintained that it was unlawful to charge interest from brothers in religion. Their teachings went as far as to suggest that when loans were advanced to other Jews they may be forgiven at the end of every sabbatical year. However, foreigners were excluded from the cancellation of debt [Benoit (1986)]. During the region of Charlemagne and the beginning of the Middle Ages, the Church as well as the State prohibited usury. According to the Church, been received.

*Owing to unavoidable circumstances, the discussant's comments on this paper have not

Habib A. Zuberi is Professor at the Department of Economics, Central Michigan University, Mt. Pleasant, Michigan.

Author's Note: I am grateful to my former graduate students Yahia Abdalla of Egypt and Mahfooz A. Jafry of Pakistan in preparing this paper. 
charging interest amounted to disobeying the Seventh commandment [Benoit 1986)].

Thus, it may be stated that the three principal monotheistic religions with roots in the Middle East, as well as the Hellenic philosophers, condemned charging interest in varying degrees. However, since the rise of capitalism, interest rates have played a central role in the development of the modern banking system. Yet, Gurley has observed "that banking system as intermediaries are not highly essential to the growth process". [Gurley (1967), p. 58)]. Cameron (1972) has pointed out that the contributions of the modern banking system have been positive, negative, and neutral in the early stages of economic development in various European countries. The degree of success depended on the support the banking industry received from the government. Thus, historically the role of the modern banking system in economic development or economic stability has produced mixed results. In recent years some Muslim countries have initiated non-interest based banking. Foremost among the countries that subscribe to this philosophy are Pakistan and Iran.

Since Islam forbids the payment of interest, what alternative mechanism will be needed to mobilise resources? Muslim economists have suggested that the operations of the banking industry should not be viewed differently than the operation of any other business activity. Banking in an Islamic system is based on the sharing of risk and profit. Hence, if a lender of resources also assumes the risk in a business, by sharing profit or loss, then the return accruing to the lender of money is acceptable. The lender's sharing in profit or loss is similar to venture capital.

On a theoretical level Mohsin Khan (1986) has demonstrated that an interest-free banking system is consistent with the Keynesian or Classical Macroeconomic Models. He has argued that fixed interest rates prevent adjustments to shocks resulting from profit or loss. It is this rigidity he concludes that could lead to financial instability. Naqvi (1982) has argued that on ethical grounds it is easy to reject the interest rate, however, "in the realm of economics, the issue is not so clear-cut". He analyses interest rates within the framework of a dynamic economic system (in real terms) and concludes that the process of Islamisation can be completed only over a period of time. Hence during this period, the institution of interest can be gradually replaced by what is known as the profit and loss sharing (or Musharika) since the institution of interest "cannot be abolished arbitrarily through an administrative fiat."

Khan and Mirakhor (1990) in describing the development of Islamic banking in Iran and Pakistan have observed that in both countries private sector deposits 
increased. Hence, the Islamic banking system can effectively mobilise resources. The authors also point out that the governments in the two countries played an important role in mobilising resources. They are uncertain about the performance of Islamic banks in the absence of government intervention.

Much of the literature on interest-free banking is of a theoretical nature, primarily because such banks have appeared on the scene only in recent years during modern times. Ali Darrat (1988) empirically examined the effect of interest-free banking on the stability of the financial system in Tunisia. His findings indicate that the public's demand for a non-interest monetary system has a structurally stable money demand. He also found that non-interest bearing monetary assets have a relatively stable velocity of money.

In 1973, Pakistan adopted a new constitution. According to Article 37 of the constitution the country was obligated to abolish riba as soon as possible. In subsequent years the Council of Islamic Ideology recommended that gradually western style banking system should be replaced by a interest-free Islamic Banking System (IBS).

In an Islamic society both hoarding of goods (ihtikar) and hoarding of cash (iktinaz) are thoroughly discouraged [El-Bdour (1984)] and condemned while the circulation of wealth is strongly emphasised. Since the hoarding of cash is virtually prohibited, members of the household are expected to make their savings available for investment. Interest-free banking, however, does not imply access to capital without cost of risk.

What mechanism will facilitate the process of making household savings available to borrowers will depend upon the type of financial institutions that a society already has or develops. There are no specific requirements about the forms of these institutions. Existing financial institutions with appropriate modifications can serve an Islamic society.

In the existing banking system interest payments have three components: basic interest, risk premiums, and administrative expenses. Under IBS only administrative expenses will be permitted [El-Bdour (1984)]. There are two specific terms that define profit and loss relationship between the borrowers and the lenders, Musharikah and Mudarabah.

Musharikah (equity participation or limited partnership) refers to a financial system in which profits and losses are shared by the borrowers and the lenders. It is "a partnership based on the joint contribution of a bank and an entrepreneur, a customer, who mutually agrees to form capital for business exploration with a prior agreement of the ratio of profit and loss" [Jafry (1991)].

Mudarabah (silent partnership or short-term commercial credit arrange- 
ments) is essentially a fiduciary relationship in which the silent partner provides capital and the active partner operates business. The share of the profit is predetermined between the contracting parties. The loss is incurred only by the supplier of capital [El-Bdour (1984)]. Musharikah and Mudarabah are two principal mechanisms defining the form of lending and borrowing in an IBS. The lender's sharing in profit or loss is similar to venture capital.

The objective of the present study is to examine the relative stability of the financial system in Pakistan. For purposes of this paper financial markets are limited to (a) non-interest bearing bank assets (currency plus demand deposits) and (b) interest-bearing banking assets (time deposits). The hypothesis is that the financial system in Pakistan will tend to be stable in the absence of interestbearing financial assets. Procedures similar to those followed by Darrat (1988) are used in this paper.

It is assumed that the monetary authorities strive to achieve a stable aggregate nominal income. In other words, the country's resources are employed close to the production possibilities frontier. A relatively high GDP, which promotes full employment, may not be high enough to cause inflation. Given these conditions if velocity (V) is stable and money supply is regulated by the monetary authorities then economic activity can be effectively regulated. If, however, $\mathrm{V}$ is unstable then the ability of the monetary authorities to influence economic activity will be somewhat limited and may contribute to the instability of the economic system.

\section{METHODOLOGY AND SOURCES OF DATA}

For the purposes of the present study a modified version of the Keynesian type demand function for money is being utilised. Accordingly, the public demands money for transactions purposes $\left(M_{t}\right)$ and for speculative purposes holds money as an asset $\left(M_{a}\right)$. Thus,

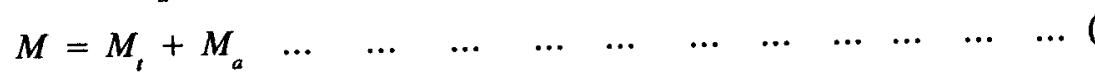

where, $M_{t}=f(Y)$, and $M_{a}=f(R)$. In other words $M_{t}$ is a function of real income $(Y)$, and $M_{a}$ is a function of interest rate $(R)$ or yield on real assets. The demand function for money, assuming no money illusion therefore, can be stated as follows:

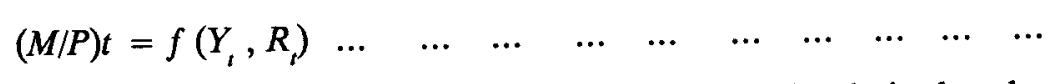

where $t$ refers to time. The above equation represents the desired real money demand. In this equation $Y$ is assumed to be similar to Fisherian equation:

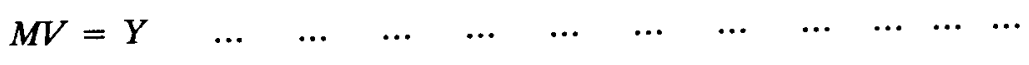


where $M V=$ money times the velocity of circulation of money and $Y$ is the gross domestic product in nominal terms. A priori it is assumed that the desired demand for real money balances $(M / P)$ will be positively related to real gross domestic product and negatively to interest rate.

By taking logarithms of the two sides of Equation (2) the following equation was obtained:

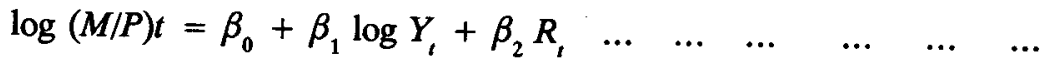

In Equation (4) $\log$ has not been taken of $R_{t}$ because it is theoretically possible that $R_{t}$ may be negative during periods of inflation (Interest rate-Inflation rate). Under such circumstances logarithms are undefined. Therefore, results would become meaningless.

It has been argued in the literature that the publics' desire to hold real money balances in time $t$ is highly influenced by the actual real money balances held in the previous time period $(t-1)$. Hence Equation (4) is adjusted by adding a lagged variable of $(M / P) t-1$ on the right hand side of the equation.

$$
\log (M / P) t=\beta_{0}+\beta_{1} \log Y_{t}+\beta_{2} R_{t}+\beta_{3} \log (M / P)_{t-1}+\xi \ldots \quad \ldots
$$

In this model $\xi$ is the error terms.

Separate estimates were made for the interest and non-interest bearing demand for money. Non-interest bearing demand for money $\left(M_{1}\right)$ consists of currency and demand deposits and the interest bearing demand for money $\left(M_{2}\right)$ consists of $M_{1}$ plus time deposits. On an a priori basis it is expected that $\beta_{1}, \beta_{3}>0$ and $\beta_{2}<0$.

The velocity $(V)$ was also estimated separately for $M_{1}$ and $M_{2}$. The estimation of velocity is based on the assumption that the monetary authorities formulate policies that would be consistent with the goal of achieving full employment with stable prices. It is further assumed the money supply $\left(M_{s}\right)$ is exogenously determined, i.e., it is controlled by the monetary authorities and $V$ is stable in the short run. Thus, by making appropriate adjustments in $M_{s}$ the monetary authorities can achieve the desired results. If, however, $V$ is unstable then it will contribute to over all instability of the economic system. Standard procedures are used in the estimation of $V$.

$$
\begin{array}{lllllllllllll}
V=Y / M & \ldots & \ldots & \ldots & \ldots & \ldots & \ldots & \ldots & \ldots & \ldots & \ldots & \ldots & \ldots
\end{array}
$$

Time-series data covering a period from 1973 to 1989 on Pakistan were obtained from International Financial Statistics (IFS). Information prior to 1973 combined data for Pakistan and Bangladesh. Hence, data prior to 1973 could 
not be used.

The IFS publishes data on money market rates, bank rates and government bond yields. An examination of the raw data shows that the bank rate has remained constant (10 percent) since 1977, and yield on government bonds is determined by the government rather than by the market forces (it has steadily declined every year from a high of 11.20 percent in 1980 to a low of 8.18 percent in 1989). Therefore, it was decided not to use bank rate and government bond yield in the model. The money market rate has been used as a proxy variable for the interest rate. The money market rate consists of representative short-term money market rates at which borrowing are affected between financial institutions or short-term government paper is issued and traded in the market.

\section{ANALYSIS OF DATA}

Separate estimates were made for the velocity of circulation of money $\left(V_{1}\right)$ for $M_{1}$ and $\left(V_{2}\right)$ for $M_{2}$. A reasonably well behaved $V_{1}$ and $V_{2}$ were observed. The $V_{1}$ fluctuated between a high of 4.3394 to a low of 3.013 with a mean of 3.67 and a standard deviation of 0.292 . The $V_{2}$ fluctuated between high of 2.941 and a low of 2.119 with a mean of 2.469 and a standard deviation of 0.2024 .

The above results indicate that both $V_{1}$ and $V_{2}$ have been stable, therefore, it may be concluded that policy actions undertaken by monetary were affective in influencing aggregate economic activity.

\section{DEMAND FOR MONEY}

In estimating Equation (5) the following log linear form was used.

$$
\log M_{t}=\alpha_{0}+\alpha_{1} \log X_{1 t}+\alpha_{2} X_{2 t}+\alpha_{3} \log X_{3 t}+\xi
$$

where, $X_{1 t}=Y_{t}, X_{2 t}=R_{t}$, and $X_{3 t}=(M / \mathrm{P})_{t-1}$

The above equation was estimated separately for $M_{1}$ and $M_{2}$. The following results were obtained.

$$
\begin{aligned}
\log M_{1 t}= & 1.749+.306 X_{1}-.0195 X_{2}+.228 X_{3} \\
& (4.750)(4.827)(-2.389)
\end{aligned}
$$

$$
R^{2}=0.9808, \text { Adjusted } R^{2}=0.9760, \text { S.E. }=0.00052 \text { D.W. }=1.862
$$


The above results indicate that the dependent variable, the desired demand for real money $\left(\log M_{15}\right)$ is positively related to real GDP, $\left(X_{1}\right.$, i.e., GDP divided by GDP deflator, $1985=100)$ and to one period lagged desired demand for $M_{1 t-1}$. The dependent variable is inversely related to the interest rate $\left(X_{2}\right)$. However, the lag of the dependent variable is not significant. The explanatory power of the model is significantly high. $D . W$. statistic suggests no problem with autocorrelation.

It may, therefore, be concluded, that the changes in real GDP exert a positive and statistically significant influence on $M_{1 t}$, and the interest rate exerts significantly negative influence on $M_{1 t}$. Information about $M_{1 t-1}$ is irrelevant in determining the desired demand for $M_{1}$. Based on the information generated by this equation over 98 percent of the variability can be accounted for in the transactions demand for money.

$$
\begin{aligned}
& \log M_{2 t}=1.988+.3758 X_{1}-.0146 X_{2}+.1259 X_{3}
\end{aligned}
$$

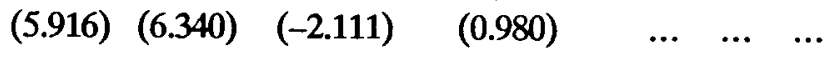

$$
\begin{aligned}
& R^{2}=0.9860 \text {, Adjusted } R^{2}=0.9825, \text { S.E. }=.00038, F=281.367 \text {, } \\
& \text { D.W. }=1.886
\end{aligned}
$$

In the above equation all variables have appropriate signs. However, the coefficients of the lagged dependent variable is insignificant and the coefficient of the interest rate at conventional $\alpha=.05$ level is not significant. The explanatory power of the model is highly significant and there is no problem with autocorrelation. The coefficient for the interest rate is significant if the lagged dependent variable is deleted from the right-hand side of the equation. ${ }^{1}$ The broader definition of $M_{2}$ includes time deposits, for periods longer than one year. The lag in $M_{2 t-1}$ is not significant partly due to the fact that the public holds assets on a long-term basis, and its presence in the model, in part, may account for the lack of significance of the interest rate also.

\section{MONETARY AUTHORITIES ABILITY TO CONTROL $M_{1}$ AND $M_{2}$}

It has been argued in the literature that the monetary authorities regulate monetary aggregates through their control over monetary base $(M B)$. For purposes of this study $M B=R+C$. Where, $R=$ Reserve deposits of the bank with the monetary authorities and $C=$ currency held by banks and nonbank public. it is assumed that the monetary authorities in Pakistan control the monetary base. By controlling $M B$ the monetary authorities can maintain or achieve economic stability. If such a link does not exist then the monetary authorities may not be able to achieve their goal. Therefore, the relationship between interest and non-interest 
bearing money stock with the monetary base is examined. The model is cast in terms of growth rates of both $M B$ and monetary aggregates of $M_{1}$ and $M_{2}$.

$$
\begin{aligned}
& \Delta M_{1}=3.76+.754 \Delta M B \\
& \text { (.977) (3.283) } \\
& R^{2}=0.4350, \text { Adjusted } R^{2}=0.3947, F=10.78, D . W .=2.560 \\
& \Delta M_{2}=4.778+.666 \Delta M B \\
& \begin{array}{lllllllllll}
(1.049) & (2.451) & \ldots & \ldots & \ldots & \ldots & \ldots & \ldots & \ldots & \ldots & \ldots
\end{array} \\
& R^{2}=0.3003, \text { Adjusted } R^{2}=0.2503, F=6.007, D . W .=1.969
\end{aligned}
$$

In the above equations $\Delta M_{1}$ and $\Delta M_{2}$ represent percentage rate of change of growth rate in $M_{1}$ and $M_{2}$ respectively. The regression equation shows the relationship between $\Delta M_{1}$ and $\triangle M B$ (percentage rate of change in $M B$, i.e., growth rate of $M B$ ). The above equations exhibit a positive relationship between $\Delta M_{1}$ and $\triangle M B$ as well as $\Delta M_{2}$ and $\triangle M B$. The coefficient of the monetary base is significant in both cases. However, $\Delta M_{1}$ and $\triangle M B$ show a stronger relationship than $\Delta M_{2}$ and $\triangle M B$. Although Equation (6.1) suggests problems with autocorrelation and Equation (6.2) shows no problem with autocorrelation, both $R^{2}$ and $F$-ratio indicate that $\Delta M B$ is a better predictor for $\Delta M_{1}$ then for $\Delta M_{2}$. It should be noted that both models are statistically significant. ${ }^{2}$

\section{SUMMARY AND CONCLUSIONS}

The present study based on time-series data covering the period from 19731989 , tests the hypothesis that the public's demand for non-interest bearing money tends to be stable relative to the interest-bearing demand for money. The multiple regression techniques are utilised in analysing data.

The empirical results reported in this paper are consistent with the theoretical model and show that the publics' desired demand for $M_{1}$ and $M_{2}$ are positively related to real GDP and negatively to interest rate. It is further established that the last years demand for $M_{1}$ plays a relatively insignificant role in the desired demand for $M_{1}$ during the current time period. The lagged variable for $M_{2}$ on the right-hand side of the equation turned out to be irrelevant in determining the desired demand for $M_{2}$. It appears that the monetary authorities in Pakistan pursued a policy which allowed relatively stable economic growth. Results reported in this paper show a well behaving velocity of money 
both of $M_{1}$ and $M_{2}$. What this study shows is that the policy-makers can effectively control both $M_{1}$ and $M_{2}$. Thus this paper supports the earlier findings of Cameron (1972), and Khan and Mirakhor (1990) that the active support by the government in the operations of the banking industry can bring about the desired results.

The results presented in this paper do not support the hypothesis that the publics' demand for money tends to be more stable in the absence of interest-bearing financial assets. This paper does show that $M B$ is a better predictor for $\Delta M_{1}$, than for $\Delta M_{2}$. It should, however, be noted that most interest-bearing financial assets have not been included in this study, largely due to the paucity of data. Furthermore, it may also be noted that the coefficient for the interest rate in the estimation of $M_{2}$ was not significant at the conventional $\alpha=.05$ level. Hence, further empirical research in the area is warranted.

Appendix

1. When lagged variable was excluded from the right-hand side of the equation, the following results were obtained:

$$
\begin{aligned}
& \begin{array}{l}
\log M_{2 t}=2.3009+.4231 X_{1}-.0169 X \\
(16.905)(12.282)(-2.582)
\end{array} \\
& R^{2}=0.9849, \text { Adjusted } R^{2}=0.9825, \text { S.E. }=.00038, F=422.859 \\
& \text { D.W. }=1.958
\end{aligned}
$$

The regression equation shows positive relationship between $\log M_{2 t}$ and $\log$ Real GDP and negative relationship between the dependent variable and money market rate. Both coefficients are significant. The model is highly significant and its explanatory power is high. The model is free from the problem autocorrelation.

2. Economic growth with price stability is considered one of the major goals of the policy-makers. Hence, economists often estimate relationship between growth rate of $M_{1}$ and $M_{2}$ with the rate of inflation. Ali Darrat (1984) had used this approach. His findings indicated autocorrelation, and low $R^{2}\left(R^{2}=0.19\right)$ for Tunisia.

Following results were obtained for Pakistan.

$$
\begin{aligned}
\Delta \text { GDPD }= & -.2307+.219 \Delta M_{1 t-1}+.2324 \Delta M_{1 t-2}-.009 \Delta M_{1 t-3} \\
& (-.052)(1.533)
\end{aligned}
$$




$$
\begin{aligned}
& R^{2}=0.4111 \text {, Adjusted } R^{2}=0.2148, F=2.094, S . E .=7.784, D . W .=1.588 \\
& \Delta G D P D=\underset{(.023)}{.0875}+\underset{(1.533)}{.2005 \Delta M_{2 t-1}+.2212 \Delta M_{2 t-2}-.0066 \Delta M_{2 t-3}}(1.779)
\end{aligned}
$$

$R^{2} .4498$, Adjusted $R^{2}=.2665, F=2.453$, S.E. $=7.27196$ D.W. $=1.742$

In the above equation $\triangle G D P D$ represent percentage of growth rate of GDP deflator. None of the coefficients are statistically significant. The value of $F$-Statistic suggest that the explanatory power of these models is not strong. In other words, changes in $M_{1}$ and $M_{2}$ with lags of 1,2 or 3 years played no significant role in determining the rate of inflation. These results are not surprising because banking industry was nationalised and the monetary authorities played an active role in adjusting money supply with the needs of the economy.

\section{REFERENCES}

Ariff, Mohammed (ed) (1982) Monetary and Fiscal Economies of Islam. Jaddah,

S. Arabia: International Centre for Research in Islamic Economies.

Benoit, J. Pierre V. (1986) United States Interest Rates and the Interest Rate Dilemma for Developing Countries. Westport, Connecticut: Quorum Books. Cameron, Rondo (1972) Banking and Economic Development. New York: Oxford University Press.

El-Bdour, Radi I. (1984) Islamic Economic System: A Theoretical and Empirical Analysis of Money and Banking in the Islamic Economic Framework. Unpublished, Ph.D. Dissertation. Economics Department, Utah State University. Darrat, Ali (1988) The Islamic Interest-Free Banking System: Some Empirical Evidence. Applied Economic 20:417-425.

Gurley, John G. H. (1967) Money, Credit, and Banking; Monetary Policy; Consumer Finance; Mortgage Credit. The American Economic Review 57:4 950-953.

Habib Banks Ltd. (1986) Towards Understanding Non-Interest Based Banking in Pakistan. Karachi: Mehran Press.

I. M. F. Bureau of Statistics (1990) Intemational Financial Statistics (Various Issues), Washington, D. C.: International Monetary Fund Publications.

International Seminar on Islamic Banking (1980) Thoughts on Islamic Banking. Dacca: Islamic Economic Research Bureau.

Islamisation Department (1985) Islamic Banking Manual. (For Official Use only). Islamabad: Agricultural Development Bank of Pakistan. Publication. 
Jafry, Mahfooz Ahmed (1991) Islamic Banking in Pakistan. Unpublished M.A. Thesis. Economics Department, Central Michigan University.

Khan, M. S. (1986) Islamic Interest-free Banking: A Theoretical Analysis. International Monetary Fund Staff Papers 33:1-27.

Khan, Mohsin S., and Abbas Mirakhor (1990) Islamic Banking: Experience in the Islamic Republic of Iran and Pakistan. Economic Development and Cultural Change 38:353-375.

Naqvi, Syed Nawab Haider (1982) Interest Rate and Intertemporal Allocative Efficiency in an Islamic Society. In Mohammad Arif (ed.) Monetary and Fiscal Economics of Islam. Saudi Arabia: International Center for Research in Islamic Economies. 75-95.

Roll, Eric (1974) A History of Economic Thought. Homewood, Illinois: Richard D. Irwin Inc.

Zanganeh, Hamid (1989) Islamic Banking: Theory and Practice in Iran. Comparative Economic Studies 31: 67-81. 